\title{
NOTES
}

\section{IDENTITY OF THE ANTITUMOR ANTIBIOTIC LITMOMYCIN WITH GRANATICIN A}

\author{
Ching-Jer Chang,* Heinz G. Floss*, \\ Pinnan Soong and Ching-Te Chang
}

Department of Medicinal Chemistry and Pharmacognosy, Purdue University, W. Lafayette, Ind. 47907, U.S.A.*

Union Industrial Research Institute Hsinchu, Taiwan, Republic of China

(Received for publication September 12, 1974)

The antibiotic litmomycin has been isolated from a new Streptomyces species, S. litmogenes $^{1)}$. The antibiotic, which is produced in yields of over $2 \mathrm{~g}$ /liter, is highly active against gram-positive bacteria (MIC $0.25 \sim 1.75 \mu \mathrm{g} / \mathrm{ml}$ ), but has little or no activity against gramnegative bacteria, mycobacterium, molds or yeast ${ }^{2)}$.

Litmomycin was produced by fermentation of $S$. litmogenes on a peanut meal-starch medium for 48 hours. The whole culture was adsorbed on charcoal at $\mathrm{pH} 4.0$ and filtered. The cake was washed with acidic water, airdried, defatted with $n$-hexane and then extracted with acetone. The eluate was evaporated to dryness the residue dissolved in dilute ammonia ( $\mathrm{pH} 8 \sim 9$ ), and the solution was acidified and extracted with ethyl acetate. Repeated recrystallization of the residue of this extract from benzene gave pure litmomycin, m.p. $223 \sim 225^{\circ} \mathrm{C}$. The antibiotic has the molecular formula $\mathrm{C}_{22} \mathrm{H}_{20} \mathrm{O}_{10}$ (M.W. 444, calc. C 59.46\%, H 4.54\%, found C 59.41, H 4.72 $\%)$; its electron-impact mass spectrum shows fragment ions at $m / e \quad 400\left(\mathrm{C}_{20} \mathrm{H}_{10} \mathrm{O}_{8}\right)$ and 384 $\left(\mathrm{C}_{20} \mathrm{H}_{10} \mathrm{O}_{8}\right)$, whereas the $\mathrm{NH}_{3}$ chemical ionization mass spectrum shows a peak at 447 , presumably corresponding to a protonated molecular ion. Other spectroscopic data for litmomycin are: $\mathrm{UV}(\mathrm{EtOH}) \mathrm{nm}(\log \varepsilon)$ : 223 (5.30), 286 (4.57), 532 (4.62) and 5.76 (4.53); IR $(\mathrm{KBr}) \mathrm{cm}^{-1}$ : 1770, 1600 and 1565; NMR (220 MHz, TFA) $\delta, p p m,(J, H z): 1.25$ (d, 7), 1.69 (d, 7), 1.89 (bd, 15), 3.00 (d, 15), ca. 3.02 (m), 3.34 (dd, 18.5), 4.23 (q, 7), 4.51 (d, 8), 5.01 (br. s), 5.34 (q, 7), 5.62(m). A comparison
Granaticin A (litmomycin)<smiles>C[C@H]1C[C@H]2CC(=O)O[C@H]2C2=C1C(=O)c1c(O)c3c(c(O)c1C2=O)[C@H]1C[C@H](O)[C@@]3(O)O1</smiles>

of litmomycin with known antibiotics by bioautography indicated that its behavior closely resembled that of granaticin, and antibiotic isolated from Streptomyces olivaceus ${ }^{3}$. Comparison of the spectroscopic data with those published for granaticin $\left.\mathrm{A}^{3}, 4\right)$ showed good agreement and a direct comparison of litmomycin with a sample of granaticin A kindly provided by Prof. H. Z̈̈HNER confirmed their identity.

Granaticin (litmomycin) has significant antitumor activity against P-388 lymphocytic leukemia in mice (T/C $166 \%$ at $1.5 \mathrm{mg} / \mathrm{kg}$ ) and cytotoxicity against $\mathrm{KB}$ cells $\left(\mathrm{ED}_{50} 1.6\right.$ $\mu \mathrm{g} / \mathrm{ml})$.

\section{Acknowledgments}

We thank Dr. D. R. BrAnNon, Eli Lilly and Co., Indianapolis, for the bioautographic comparison, Prof. Dr. H. ZÄHNER, Tübingen, Germany for the reference sample of granaticin A and the US Public Health Service for financial support (Grant AI 11728).

\section{References}

1) Soong, P. \& A. A. AU: Taxonomic studies on Streptomyces litmogenes, litmomycin-producing culture. Rep. Taiwan Sugar Expt. Station 29: 33 42, 1962

2) Soong, P.; Y.Y. Jen, Y.S. Hsu \& A.A. Au: Fermentation, isolation and properties of litmomycin, Rep. Taiwan Sugar Expt. Station 34: $105 \sim 117,1964$

3) Corbaz, R.; L. Ettlinger, E. Gaümann, J. Kalvoda, W. Keller-Schierlein, F. Kradolfer, B.K. Manukian, L. Neipp, V. Prelog P. Reusser \& H. ZÄHNER: Stoffwechselproduke von Actinomyceten. Granaticin. Helv. Chim. Acta 40: 1262 1269, 1957

4) Keller-Schierlein, W.; M. Brufani \& S. BARCZA: Die Struktur des Granaticins und Granaticins B.I. Spektroskopische Eigenschaften und Chemischer Abbau. Helv. Chim. Acta 51: 1257 1268, 1968 